\title{
Stage IIIC Colon Cancer AJCC v7
}

National Cancer Institute

\section{Source}

National Cancer Institute. Stage IIIC Colon Cancer A/CC v7. NCI Thesaurus. Code C115049.

Stage IIIC includes: (T4a, N2a, M0); (T3-T4a, N2b, M0); (T4b, N1-N2, M0). T3: Tumor invades through the muscularis propria into pericolorectal tissues. T4a: Tumor penetrates to the surface of the visceral peritoneum. T4b: Tumor directly invades or is adherent to other organs or structures. N1: Metastasis in 1-3 regional lymph nodes. N2: Metastasis in four or more regional lymph nodes. N2a: Metastasis in 4-6 regional lymph nodes. N2b: Metastasis in seven or more regional lymph nodes. M0: No distant metastasis. (AJCC 7th ed.) 